\title{
Engelli Bireylerin Erişilebilir Turizm Beklentilerinin Değerlendirilmesine Yönelik Nitel Bir Araştırma
}

\author{
A Qualitative Research on Evaluation of Accessible Tourism Expectations of People with Disabilities
}

\author{
Zeki AKINCl*, Nesrin SÖNMEZ** \\ * Yrd. Doç. Dr., Akdeniz Üniversitesi, Turizm Fakültesi, 07058, Arapsuyu Kampusu, Antalya. \\ E-posta: zakinci@akdeniz.edu.tr \\ **Yrd. Doç. Dr., Akdeniz Üniversitesi, Eğitim Fakültesi, 07058, Arapsuyu Kampusu, Antalya. \\ E-posta: ndilersonmez@gmail.com
}

\section{MAKALE BILGILERI}

Makale işlem bilgileri:

Gönderilme tarihi: 1 Ekim 2013

Birinci değerlendirme: 23 Aralı 2013

İkinci değerlendirme: 4 Şubat 2014

Üçüncü değerlendirme: 5 Mart 2014

Kabul: 14 Nisan 2014

Anahtar sözcükler:

Engelli, Kamu ve sivil toplum örgütle-

ri, Erişilebilir turizm.

\section{ARTICLE INFO}

Article history:

Submitted: 1 October 2013

Resubmitted: 23 December 2013

Resubmitted: 4 February 2014

Resubmitted: 5 March 2014

Accepted: 14 April 2014

Key words:

Disabled, Governmental and

non-governmental organizations,

Accessible tourism.

\section{ÖZ}

Engelli insanlar için hazırlanan bütün yapıların, süreçlerin ve sistemlerin başta erişebilirlik olmak üzere belirli özelliklere sahip olmaları ve bu özelliklerin zaman içerisinde geliştirilmesi gerekmektedir. Bu çalışmada, engellilerin turizm hizmetleri ile ilgili genel beklentilerinin derinlemesine değerlendirilmesi hedeflenmiştir. Bu bağlamda, ilgili kamu ve sivil toplum kurulușları yöneticileriyle engelliler ve engelli ailelerinin beklentilerine ilișkin görüșlere ulaşma konusunda çalışma yapılmıştır. Araştırma verilerinin toplanabilmesi için ilki görüşme yapılan kişilerin demografik bilgilerinin yer aldığı bilgi formu, diğeri ise yarı-yapılandırılmış görüşme sorularını içeren iki adet ölçü aracı geliştirilmis ve kullanılmıștır. Bu calıșmada, engelli insanların turizm faaliyetine katılmasında en önemli engellerin; ekonomik, fiziki ve ulaştırma ile ilgili koşulların olduğu belirlenmiştir. Belirtilen bu koşulların sağlanması durumunda erişilebilir turizm kapsamında her türlü turizm faaliyetinin engelli insanları mutlu edebileceği ortaya konulmuştur.

\section{GiRiş}

Doğuştan ya da sonradan çeşitli nedenlerle engelli olan insanlara sunulacak hizmetler, sadece engelli insanların değil, aynı zamanda başta yaşlı insanlar, hamile kadınlar ve çocuklar olmak üzere diğer nor-

\footnotetext{
1. Bu makale Akdeniz Üniversitesi Proje Geliştirme, Uygulama ve Araştırma Merkezi (APGEM) ve Batı Akdeniz Kalkınma Ajansı (BAKA) tarafından yürütülen "Engelsiz Antalya-Engelsiz Turizm" başlıklı sanayi ve turizm sektörlerinde rekabetçiliğin artırılması çerçevesinde yürütülen projeden üretilmiştir.
}

mal insanların da faaliyetlere daha rahat ve kolay bir şekilde erişebilirliğini sağlayacak ve onların da yaşam kalitelerinin artmasına katkı sağlayacaktır. Çağdaş toplum oluşturulmasında, engelli insanların toplumsal yaşama katılımının önündeki engellerin kaldırılması ve yaşamın tüm kesimlerine uyumlarının sağlanması önemli bir göstergedir. Sunulacak olan hizmetlerin belirlenmesi ve kriterlerinin sağlanmasında engelli ve engelli yakınlarının doğru bir şekilde ihtiyaç ve beklentilerinin değerlendirilmesi gerekmektedir. Böylece, hem 
engelli insanların eşit ve onurlu bir şekilde turizm faaliyetlerinden yararlanması, hem de turizm işletmelerinin yoğun rekabet koşulları altında istenilen doluluk ve gelir hedeflerine ulaşması söz konusu olabilir.

Uluslararası Birleşmiş Milletler Örgütü tarafından dünyanın en büyük azınlığı olarak adlandırılan engelli insanların sayısı, nüfusların yaşlanması ve yaşlı insanların engelli hale gelme riskinin yüksek olması ile birlikte daha da artacaktır. Engelli insanların ve bütün toplumun faydalanması adına; engelleri ortadan kaldıracak koşullar yaratmak, rehabilitasyon ve destek hizmetlerini geliştirmek, yeterli sosyal koruma sağlamak, kapsayıcı politikalar ve programlar oluşturmak, var olan ve yeni evrensel standartlar ile yasaları yürürlüğe sokmak için bütün ilgili paydaşlara, hükümetlere, sivil toplum örgütlerine ve engelli insanların örgütlerine önemli görevler düşmektedir. Bu çabaların merkezinde engelli insanlar olmalıdır (WHO 2011). Bu bağlamda, Dünya Turizm Örgütü tarafından seyahat etme hakkının insan mutluluğu için gerekli temel bir insan hakkı olduğu ve turizmin insan sağlığına hizmet eden temel bir gereksinim olduğu öngörülmektedir. Turizmde Global Etik İlkeler kapsamında; dünyanın sahip olduğu değerler tüm insanlara açık olduğu, turizm faaliyetinin, insan haklarının gelişmesine katkı sağlaması gerektiği, tüm insanların turizme katılma hakkı çerçevesinde, engellilerin turizm hareketine katılmasının kolaylaştırılmaS1 ve teşvik edilmesi vurgulanmıştır (WHO 1999).

Yaşamlarını geçici ya da kalıcı herhangi bir tür engellilik ile sürdürmek zorunda kalan insanlara hizmet sunmayı hedefleyen erişilebilir turizm, engellileri toplumdan dışlamayı değil, topluma katmayı öngörmektedir. Engellilerin topluma bağımsız dâhil edilmesi stratejisi doğrultusunda engelli bireylerin saygın ve eşit muamele ile özgürce tatil yaparak toplumsal yaşama katılma haklarına erişimlerinin sağlanması yer almaktadır. Erişilebilir turizmi, sunulan ürün ve hizmetler ne olursa olsun başta engelli insanlar olmak üzere tüm insanlara kısıtlı fiziksel hareket kabiliyetine sahip olup olmadıklarına bakılmaksızın sürdürülebilir hizmet sunma ve beklentilerin karşılanması çabası olarak tanımlayabiliriz. Bu bağlamda erişilebilir turizm, yerli ve yabancı turistlerin tatillerini sorunsuzca geçirmelerine imkân sağlayacak erişilebilirlik çalışmalarının evrensel boyutta doğru biçimde yapılması ile mümkün olabilir.
Kültür ve Turizm Bakanlığı'nın 2012 Konaklama İstatistikleri Raporu'na göre, Antalya Bölgesi Türkiye'nin turistik işletme belgeli konaklama işletmelerinin yatak kapasitesinin $\% 42,18$ 'ini ve geceleme sayısının \%56,15'ini karşılamaktadır. Yıllık doluluk oranının $\% 63,22$ ve ortalama geceleme sayısının kişi başı 5,3 geceleme olduğu rapordan anlaşılmaktadır (KTB 2013). Bu rapordan elde edilen verilere göre, yıllık \%37 dolayında atıl yatak kapasitesi bulunmaktadır. Bu bağlamda, erişilebilir turizmin hayata geçirilmesinin Türkiye ve Antalya Bölgesi turizmine önemli katkılar sağlayacağ 1 aşikârdır. Bu nedenle, herhangi bir nedenle engellilik durumu ile geçici veya kalıcı olarak yaşamlarını sürdürmek zorunda kalan insanların turizm faaliyetlerine katılabilmesi için erişilebilir turizmin önündeki ekonomik, fiziksel ve ulaştırma ile ilgili engellerin ortadan kaldırılması ve ilgili kamu, özel sektör ve sivil toplum örgütlerinin üzerlerine düşen sorumlulukları yerine getirmeleri gerekmektedir.

TÜRSAB (2008) raporuna göre, İngiliz Üniversitesi Surrey tarafından yürütülen OSSATE (OneStop-Shop Accessible Tourism in Europe) "Erişilebilir Pazar ve Paydaş Analizi-2005" çalışmasında Avrupa'da 46 milyona yakın fiziksel ya da zihinsel sorunu bulunan engellinin yaşadığını ortaya koymaktadır. Hareket zorluğu yaşayan hamile kadınlar ve 65 yaş üzeri nüfus göz önüne alındığında bu rakam 130 milyon kişiye ulaşmaktadır. Araştırma sonuçlarına göre bu nüfusun yaklaşık yüzde 70'i seyahat ediyor. Bu kişilerin genellikle bir ya da birkaç kişinin refakatiyle seyahat ettikleri düşünüldüğünde Avrupa'da seyahat eden potansiyel rakamın 130 milyon kişi ve bunların yaklaşık turizm harcamasının 80 milyar Avrodan fazla olduğu tahmin edilmektedir. Ayrıca, ABD'deki engellilerin toplam nüfusunun ise 50 milyona yaklaştığ 1 ve bu kesimin alım gücünün 175 milyar dolara ulaştığı ifade edilmektedir. Yıllık turizm harcaması tutarı 13,6 milyar dolardır. Dünyanın büyüyen ekonomisi Çin'de 60 ve gelişmiş Japonya'da 5 milyon engelli bulunmaktadır. Engelli insanların büyük bölümünün en az bir refakatçi ile seyahate çıkması ve turizm faaliyetine katılması düşünüldügünde daha fazla geceleme ürettikleri ortaya çıkmaktadır. KTB (2013) yıllık raporuna göre 2012 yılında Türkiye'ye gelen toplam turist sayısinın 31,7 milyon ve elde edilen turizm gelirlerinin 23,4 milyar dolar olduğu verileri göz önüne alınırsa, engelli insanların oluş- 
turduğu turizm pazarının önemi daha iyi anlaşılmaktadır. Bu bağlamda Birleşmiş Milletler Örgütü tarafından "dünyanın en büyük azınlığı" olarak tanımlanan engelli insanların beklentilerinin belirlenmesi ve bu doğrultuda düzenlemelerin (hukuksal, kamusal ve sektörel) yapılması turizm sektörü ve bu sektörde faaliyet gösteren işletmelerin rekabet edebilmeleri ve yaşamlarını sürdürebilmeleri açısından büyük bir önem arz etmektedir.

\section{Nitel Araştırmanın Amacı}

Nitel araştırmalar genelleme yapma amacı taş1madığından, incelenen olay ya da olguyu ölçmekten ziyade derinlemesine anlamaya çalışmak daha önemlidir. Bu nedenle geniş bir örneklem kitlesiyle çalışmak yerine araştırmanın amacına uygun küçük bir örneklem grubuyla çalışılması daha faydalı olmaktadır. Dolayısıyla nitel araştırmalarda sıklıkla amaçlı örnekleme yöntemi kullanılmaktadır. Amaçlı örneklemin mantığ ve gücü derinlikli çalışmalar için bilgi açısından zengin durumlar seçilmesini sağlar (Glesne 2013). Derinlemesine görüşme bir veri toplama tekniği olarak; açık uçlu soruların sorulması, etkin dinlenmenin yapılması, yanıtların kaydedilmesi ve ilişkili ek sorularla araştırma konusunun detaylı bir şekilde incelenmesini mümkün kılar. Derinlemesine görüşme yoluyla sosyal dünyada görünür halde bulunan birçok olgu, süreç ve ilişkinin görünümünden çok özüne inilmesi, bunların ayrıntılarının kavranması ve bütüncül bir şekilde anlaşılması hedeflenmektedir (Kümbetoğlu 2005).

Bu nitel çalışmada, Akdeniz Bölgesinde bir üniversitenin turizm sektöründe rekabetçiliğin arttırılması kapsaminda yürütülen "Engelsiz Turizm Projesi" çerçevesinde aynı bölgede üç ilin Kültür ve Turizm İl Müdürlükleri ve Aile ve Sosyal Politikalar İl Müdürlükleri ile engelli insanlara hizmet sunmak amaciyla kurulmuş sivil toplum örgütleri temsilcileri ile görüşmeler yapılmıştır. Engelli insanların ve ailelerinin çeşitli nedenlerden dolayı eşit ve onurlu bir şekilde turizm faaliyetlerine yeterince katılamadıkları ve seyahat etme haklarından faydalanamadıkları genel bilinen bir durumdur. Engellilerin ve ailelerinin en doğal hakları olan turizm faaliyetine katılmasında engel olarak gördükleri unsurlar söz konusudur. Bu nedenle görüşmelerde turizm faaliyetine katılma konusunda engelliler ve engelli ailelerinin sorunlarına ve bek- lentilerine ilişkin görüşlere ulaşılması amaçlanmıştır. Çalışmanın genel amacına dönük olarak değerlendirilmek üzere alt amaçlara yanıtlar aranmıştır. Bu nitel çalışmada engellilerin turizm hizmetleri ile ilgili genel beklentilerinin derinlemesine değerlendirilmesi hedeflenmiştir. Ayrıca, bu çalışmanın engelli insanların turizm faaliyetlerine katılımı önündeki engellerle mücadele çalışmalarına ve bu alanda yapılacak olan bilimsel nicel araştırmaların alt yapisını oluşturmasına katkı sağlayacağı düşünülmektedir.

Çalışmanın ana amacı, genel olarak tatil yapmak konusunda engelliler ve engelli ailelerinin beklentilerine ilişkin görüşlere ulaşmaktır. Çalışmanın amacına dönük olarak değerlendirilmek üzere aşağıdaki sorulara yanıt aranmıştır:

1) Katılımcıların görme/işitme/bedensel engellilerin tatil yapma olanakları hakkındaki görüşleri nedir?

2) Görme/işitme/bedensel engelli bireyler ne tür tatil yapmayı tercih etmektedir?

3) Katılımcılara göre tatil organizasyonu için bulundukları yerden, gittikleri kuruluşlara, tatil yöresine ve tatil binasına erişimleri ve tatil ortamı içinde hareketlilikleri açısından engellilerin ne tür talepleri/gereksinimleri olmaktadır ya da olabilir?

4) Katılımcılara göre mevcut turizm hizmetleri, engellilerin taleplerini/gereksinimlerini ne düzeyde karşılayabilmektedir? Karşılaştıkları sorunlar nelerdir?

5) Katılımcılara göre engellilerin turizm hizmetlerinden yararlanmasını sağlamak üzere turizm aracıları, engelli STK'ları ve devletin ilgili organlarına ne gibi görevler düşmektedir?

6) Katılımciların engellilerin tatil konusunda karşılaştıkları sorunların çözümüne yönelik ne tür önerileri vardır?

\section{ALANYAZIN TARAMASI}

Engelli, faaliyetlerini sınırlayan fiziksel bir bozukluğa sahip olan bir birey olarak tanımlanabilir (Burnett ve Baker 2001). Bu yaklaşım Nicolle ve Peters'in (1999) engelli olmanın, kullanıcının ihtiyaçları ile yetenekleri ve çevresi arasındaki bir uyuşmazlığın sonucu olduğu yaklaşımı ile uyumludur. Özürlüler İdaresi Başkanlığı (ÖZIDA) (2010) raporunda 
engelli, "doğuştan veya sonradan herhangi bir nedenle bedensel, zihinsel, ruhsal, duygusal ve sosyal yeteneklerini çeşitli derecelerde kaybetmesi nedeniyle normal yaşamın gereklerine uyamama durumunda olup; bağımsız hareket edebilmesi için yapılarda ve açık alanlarda özel fiziki düzenlemelere gereksinim duyan kişi" olarak tanımlanmaktadır. Aynı raporda, özürlü kişiler ile bunların çevreleri arasındaki bir ilişki sonucu, özellikle toplumsal faktörlerle ortaya çıkan ve engelliliğe yol açan, yapılı çevre içindeki fiziksel, kültürel veya sosyal k1sitlllıklar ise engel olarak ifade edilmiştir (ÖZİDA 2010).

Engellilik heterojen bir yapıya sahiptir. Engelliliğin çeşitli şekilleri (cinsiyet, yaş, rrk / etnisite, kültür, sosyo-ekonomik durum, cinsel yönelim gibi diğer öznellikleri ile birlikte) turist deneyimlerini farklılaştırmaktadır. Hatta benzer engelli grubu içerisinde engellilik düzeyinin tipine ve seviyesine göre farklı seyahat şekilleri planlamak gerekmektedir (Small vd. 2012). Fiziksel engellilerle yaşamak birçok güçlügü de beraberinde getirmektedir. Fiziksel engellilerle turizm faaliyetlerine katılmak da bir orkestra gibi fiziksel, ruhsal birçok problemle başa çıkmakla mümkündür. Kabul edilen görüşe göre, turizm faaliyetlerine katılmak fiziksel engeli olan ve olmayan tüm insanlar için gerekli bir aktivitedir. Ama fiziksel engelliler için turizm faaliyetlerine katılıp mutlu olmak, sosyal ve pratik olarak değişik türde güçlüklerin üstesinden gelmeyi de gerektirmektedir (Germ ve Schleien 1997).

Bir milyardan fazla insanın veya dünya nüfusunun yaklaşık yüzde 15'inin (2010 dünya nüfus tahminlerine göre) bir tür engellilik ile yaşadığ 1 tahmin edilmektedir (WHO 2011). Uluslararası Birleşmiş Milletler Örgütü tarafından dünyanın en büyük azınlığı olarak adlandırılan engelli insanların sayısı (Artar ve Karabacakoğlu 2003), nüfusların yaşlanması ve yaşlı insanların engelli hale gelme riskinin yüksek olması ile birlikte daha da artacaktır. Yapılan çalışmalar, nüfusun \%30'unun yaşamının herhangi bir noktasında belirli bir aşamada engelli olacağını ve erişim gereksinimlerine ihtiyacı olacağını göstermektedir (Darcy 2009). Bu sayıya hareketleri kısıtlanmış yaşlı insanlar, hamileler, çocuklar ve aileleri eklenecek olursa, engelli dünyasının toplam rakamı dünya nüfusunun neredeyse yarısını oluşturduğu görülmektedir.
Kişilerin doğuştan veya sonradan herhangi bir hastalık veya kaza sonucu bedensel, zihinsel, ruhsal, duyusal ve sosyal yeteneklerini çeşitli derecelerde kaybetmesi nedeniyle engelli olması ve yaşamsal kapasitelerinin engellenmesi, bu durumdaki kişilerin yaşamsal aktivitelerini kısmi ya da tam olarak engellemekte ve de en önemlisi sosyal yaşamlarını sürdürmelerini zorlaştırmaktadır (TUIK 2002). Dünya Sağlık Araştırması sonuçlarına göre, engellilik düşük gelirli ülkelerde yüksek gelirli ülkelere göre daha yaygındır. Aynı zamanda, en yoksul bește birlik refah diliminde yer alan insanlarda, kadınlarda ve yaşlı insanlarda engellilik daha fazla yaygınlık gösterir (AIHW 1997). ICF (International Classification of Functioning, Disability and Health-Uluslararası İşlevsellik, Engellilik ve Sağlık Sınuflandırmasi) ve CRPD (Convention on the Rights of Persons with Disabilities-Engellilerin Haklarına İlişkin Birleşmiş Milletler Sözleşmesi) kriterlerine göre çevrenin engelli insanların katılımını kısıtlayan yaygin engelleyici faktörler; yetersiz politikalar ve standartlar, olumsuz tavırlar, yeterli hizmet sağlanmaması, hizmet iletimi sorunları, yetersiz finansman, yetersiz erişilebilirlik, danışma ve katılım yetersizliği ve veri ve bulgu yetersizliği olarak belirtilmiştir (WHO 2011).

1981 yılının Birleşmiş Milletler tarafından "Uluslararası Engelliler Yılı" olarak ilân edilmesiyle, bu gruptaki insanlara yönelik davranışlarda önemli ölçüde anlayış değişikliği gözlenmiştir. Bu değişikliği pekiştirmek amacıyla, yine Birleşmiş Milletlerce 1983 - 1992 yılları "Engelli İnsanlar On Yılı" olarak belirlenmiş, bu dönemde belirginleşen ve "Engelli İnsanlara Yönelik Dünya Eylem Programı" ile daha da gelişen anlayış, günümüzde çağdaş toplumun vazgeçilmezleri arasına girmiştir (Artar ve Karabacakoğlu 2003). 2006 yilında benimsenen Engellilerin Haklarına İlişkin Birleşmiş Milletler Sözleşmesi'nin amacı, "tüm engelli insanların temel özgürlüklerden ve bütün insan haklarından tam ve eşit bir şekilde faydalanmasını teşvik etmek, sağlamak, korumak ve insan olmaktan ileri gelen haysiyetlerine yönelik saygıyı arttırmaktır" (ÖZIDA 2013). Bu, dünya çapında engelliliğe yönelik anlayışta ve verilen tepkilerde büyük bir değişimi ifade etmektedir.

Her ülke, turistik destinasyonlarının ortak ve farklı özelliklerine ve değerlerine dikkat çekmeyi, turizmin sosyal, kültürel ve çevresel sürdürülebi- 
lirliğini sağlayarak ekonomik gelişmeyi teşvik etmeyi amaçlamaktadır (KTB 2013). Bir yandan her ülke, küresel boyutta yoğun rekabetin yaşandığ1 turizm sektöründe deniz, kum, güneş üçgeni olarak adlandirılan kitle turizminde en uygun fiyatla en iyi hizmeti vererek turizm pastasından istenilen payı almak için uğraşırken, diğer yandan farklı alternatif turizm türlerine yönelerek turizm pastasından payını artırmayı hedeflemektedir. Bu bağlamda, Birleşmiş Milletler Organizasyonu tarafından dünyanın en büyük azınlığı olarak adlandırılan engellilerin oluşturduğu turizm pazarı en önemli ve özel pazarlardan birini oluşturmaktadır.

Engelli turizmi yerine daha kapsayıcı ve ayırımcı olmayan, herkesi kapsayan erişilebilir turizm kavramını kullanmak, daha genel kabul gören bir yaklaşımdır. Erişilebilir turizm kavramı konusunda kabul görmüş tek ve evrensel bir tanım yoktur. Bu kavramın içeriğinin süreç içerisinde dünyada yapılan araştırmalar ve uygulamalar doğrultusunda geliştirileceği muhakkaktır. Erişilebilir turizm kavramının aynı zamanda "evrensel turizm", "engelli turizmi" "engelsiz turizm", "herkes ve/veya her şey dâhil turizm" gibi farklı adlarla da kullanıldığ1 görülmektedir. 2009 yılında UNESCAP tarafından yapılan ESCAP-Takayama 2009 Kongresi sonucunda yapılan bildirgede erişilebilir turizm; "hareket, işitme, görme, bilişsel veya entelektüel ve psikososyal engelliler, yaşlılar ve geçici engelliler dâhil olmak üzere tüm engelli ve engelsiz insanların erişilebilirliğini sağlayan turizm ve seyahat faaliyeti" olarak tanımlanmaktadır (ENAT 2012).

Erişilebilir turizm; hareketlilik, görme, işitme ve bilişsel erişim boyutu dâhil olma üzere, erişim gereksinimine sahip olan insanlara bağımsız, eşit ve onurlu bir şekilde evrensel tasarımlı turizm ürün ve hizmetlerini ve çevreyi kullanma imkânını sağlamaktadır (Darcy ve Dickson 2009). Engelliler için erişilebilir turizm imkânının sağlanması hükümetlerin sorumluluğundadır (Poria vd. 2010). Dünyanın en büyük azınlığı olarak nitelenen engelliler, turizm sektörü için dünyanın en büyük özel pazarı haline gelmiştir. Engelliler için yıllardır ihmal edilmiş etkili yasal düzenlemeler birçok ülkede (özellikle de gelişmiş ülkelerde) hayata geçirilmeye ve yavaş yavaş etkisini göstermeye başlamıştır. Geçmişe oranla çok daha mobil hale gelmiş, çeşitli ekonomik ve sosyal olanaklara kavuşmuş engellileri, seyahat etmeye ve turizm faaliyetlerine katılmaya giderek daha da yakınlaştırmıştır (TÜRSAB 2008).
Günümüzde, turizm endüstrisi için engelliler önemli bir niş pazar konumunda olmalarına rağmen, bugüne kadar üzerinde fazla durulmamıştır (Israeli 2002). Bununla birlikte turizm alanyazınında engelli turistlere giderek dikkat çekildiği görülmektedir (Chou ve Chao 2007; Huh ve Singh 2007; Gröschl 2007; Yates 2007; Eichhorn vd. 2008). Akademik alanda yeterli olmasa da yapılan çalışmalarla engelli insanların turizm sektörü açısından önemli bir potansiyel oluşturduğu ifade edilmesine rağmen ne yazık ki; kamu ve özel sektör temsilcileri bu pazarın varlığ 1 ve önemi konusunda yeterince bilince sahip değildirler (Tellan ve Yılmaz 2007). Son on yılda engellilerin turizme katkıları yapılan bilimsel çalışmalarla da ortaya konulmuştur (Neumann ve Reuber 2004; Buhalis vd. 2005; Van Horn 2007; Dwyer ve Darcy 2008). Ancak, günümüzde hala insan hakları ve ekonomik argümanlar alanında iyileştirmelere rağmen, engellilerin turizmin tüm bileşenlerine ulaşmaları konusunda engeller var olmaya devam etmektedir (Smith 1987; Turco vd. 1998; Darcy 2002; Daniels vd. 2005).

Engelli insanların da diğer insanlar gibi turizm faaliyetlerine katılmaları en doğal hakları olmalarına rağmen, turizm faaliyetleri sanki engeli olmayan kişiler için tasarlanmış şekildedir (Yau vd. 2004). Hatta engelli insanların da rahat bir şekilde turizm faaliyetine katılabilmeleri için tasarlanmış kamuya ait Avrupa'nın ve Türkiye' nin en büyük ve donanımlı engelli oteli Marmaris Panorama Park Otel'in, "engelli insanlar geliyor ve konakliyor" diye engelsiz diğer insanların oteli terk etmesi ve otele gelmeyi tercih etmemesi nedeniyle sadece engelli insanlara hizmet sunması gibi olumsuz bir örnek oluşturması, insanların ve kamunun erişilebilir turizm konusundaki bilinç yetersizliğini ortaya koymaktadır (Akıncı 2013). Görüldüğü gibi engellerle yaşamak birçok güçlügü de beraberinde getirmektedir. Kabul edilen görüşe göre, turizm faaliyetlerine katılmak engeli olan ve olmayan tüm insanlar için gerekli bir aktivitedir. Ancak, engellilerin turizm faaliyetlerine katılma ve mutlu olmaları için sosyal ve pratik olarak değişik türde güçlüklerin üstesinden gelmeleri gerekmektedir (Germ ve Schleien 1997).

Ne yazık ki, erişilebilir turizm konusunda yapılan akademik çalışmaların yetersiz olduğu ilgili alanyazından anlaşılmaktadır (Burnett ve Baker 2001; Darcy 2002; Ray ve Ryder 2003). Konu ile il- 
gili çalışmalar 1980'li yılların sonları ile 1990'lı yılların ortalarından itibaren özellikle yasal düzenlemelere paralel olarak hız kazanmıştır. Ray ve Ryder (2003) çalışmalarında; ABD engelli pazarı üzerinde durarak, $\mathrm{ADA}^{\prime}$ nın (The Americans With Disabilities Act) getirdiği sonuçlara bağlı olarak 36 milyon kişinin seyahat etme fırsatından bahsetmiştir. Bu bağlamda, araştırmacılar engellilerin seyahat planlamasında daha önceden seyahate ç1kan engellilerin tavsiyesi, internet ve seyahat acentelerinin tavsiyeleri ile seyahat kararları aldıkları, engellilerin seyahatlerinde sportif aktivitelere de katıldıkları ve engellilerin seyahatlerini planlarken bilinçli davrandıklarını ortaya koymuşlardır (Yaylı ve Öztürk 2006). Coles ve Shaw (2003) yaptıkları çalışma ile İngiltere'de engellilere yönelik 1995 yılında Engellileri Koruma Kanunu'nun (DDA-Disability Discrimination Act) çıkarılmasindan sonra, söz konusu pazar diliminin ekonomik anlamda gittikçe daha önemli hale geldiğini ortaya koymuşlardır. Türkiye'de de 2005 yılında “Özürlüler Kanunu" nun kabul edilmesiyle birlikte ülkemizde yaşayan veya ülkemize gelen engelli insanların turizm hareketi içerisinde yaşam standartlarını iyileştirmek amacıyla Kültür ve Turizm Bakanlığı tarafından çeşitli düzenlemelerin yapılmasında ve yaptırımların uygulanmasinda ivme kazanılmıştır (TÜRSAB 2008). Yau vd. (2004) engellilerin seyahatleri sürecinde; kişisel faktörler, bağlantılar kurma, analiz, seyahati gerçekleştirme, deneyim ve geri besleme olmak üzere beş farklı aşamadan geçtiğini ortaya koymuşlardır. Cavinato ve Cuckovich'in (1992) yaptığı araştırmada ise ABD ulaştırma sektörünün engelliler için uyumlaştırılması konusunu ele almıştır. Öte yandan, Daniels vd. (2005), engellilerin seyahatlerinin tüm aşamalarında ihtiyaçlarını giderici tedbirlerin alınması gerektiğini ifade etmişlerdir.

Dünya Sağlık Örgütü ve Dünya Bankası tarafından hazırlanan 2011 Dünya Engellilik Raporu'nda engellilerin beklentilerinin karşılanması için bütün alanlarının kesiminde dokuz öneride bulunmuştur. Bu önerilerin uygulanabilmesi için hükümetler, sivil toplum örgütleri (engelli örgütleri de dâhil olmak üzere), profesyoneller, özel sektör, engelli insanlar ve aileleri, kamu ve medya birlikte hareket etmek durumundadır. Bu öneriler; tüm politikalara, sistemlere ve hizmetlere erişimin sağlanması, engelli insanlara yönelik özel program ve hizmetlere yatırım yapılması, ulusal bir engellilik stratejisi ve eylem planı benimsenmesi, engelli insanların süreçlere dâhil edilmesi, insan kaynağ 1 kapasitesinin geliştirilmesi, yeterli finansmanın temin edilmesi ve hizmetlerin insanların bütçesine uygun olmasının sağlanması, toplumun engelliliğe dair farkındalığının ve anlayışının geliştirilmesi, engellilikle ilgili yeterli veri toplanması ve engellilik araştırmalarının desteklenmesi ve geliştirilmesi şeklinde sayılabilir (WTO 2011).

\section{YÖNTEM}

\section{Nitel Araştırma Yöntemi}

Bu çalışmada nitel araştırma yöntemi uygulanmıştır. Bu yöntem, alanyazında nicel çalışmalara yer verilmekle birlikte bu konuda yapılmış nitel çalışmaların son derece az olması nedeniyle ve tüm aktörlerin derinlemesine görüşlerine ulaşılabilmesi için seçilmiştir. Ayrıca, bu konu ile ilgili yapılacak olan nicel bir araştırma çalışmasına katkı sağlaması hedeflenmiştir. Genel olarak nitel araştırma yöntemi uygulamanın amac1; bu yöntemin, üzerinde araştırma yapılan kişilerin sahip oldukları deneyimlerden doğan anlamların sistematik olarak incelenmesine, doğal ortama duyarlılık sağlamasına, araştırmacının katılımcı rolünün olmasına, algıların belirlenmesini sağlamasına, araştırma deseninde esnekliğin olmasına ve tümevarımcı bir analize sahip olmasına imkân sağlamasıdır.

Nitel araştırmada elde edilen bulguların genellemesi güçtür. Araştırmanın raporlanması aşamasında herhangi bir genelleme yerine, bizimle araştırma sürecini paylaşmış kişilerin görüşlerini yansıttıkları anlam sistemlerini, sosyal hayata dair algılarını ortaya koymak önemlidir. Bütüncül bir anlama çabası, her görüşmeden çıkan farklı anlatılardan ortak çizgileri, benzerliklerin yanı sıra beliren farklılıkları raporlamada açıklıkla sunmayı, araştırma sürecinde paylaşılan bilgilerden gerçekliğin resmini doğru kavramayı içermelidir (Kümbetoğlu 2005). Bu yüzden insan bilimlerinde -bir kez bulundu mu daima ve her yerde geçerli olacakgenel doğa yasalarına ulaşma durumu bir yanılsama (kurgu) olarak tanımlanır. Araştırma sonuçlarının genelleştirilebilirliği, nitel düşünce biçimine göre daima özgül olaylarla gerekçelendirilmelidir. Bu bağlamda bulunan sonuçların diğer durum ve zamanlar için nasıl bir geçerliliği olacağına ilişkin 
argümanlar verilmeli; hangi durumlarda, hangi zamanda geçerli olduğu açıklığa kavuşturulmalıdır (Mayring 2011). Ayrıca, nitel araştırmalarda davranışların, tutumların ve olayların zaman içinde farklı dönemlerde, farklı toplumlarda/bireylerde değişiklik gösterebileceği düşüncesi ile sonuçların genellenmesi amaçlanmaz. Bunun aksine nitel araştırmalarda derinlemesine inceleme, detaylarıyla anlama çabası hâkimdir. Bu nedenle, nitel araştırmalarda, bilimsel araştırmaların özelliklerinden biri olan genellenebilirlik boyutunun sağlanabilmesi için yapılan çalışmanın nicel bir araştırma ile desteklenmesi gerekmektedir (Ataseven 2012).

Nitel araştırmalarda örneklem büyüklüğünü hesaplamanın belli bir kuralı yoktur. Örneklem; araştırmanın amacına, araştırma için ayrılan kaynağa, araştırma sorularına ve sınırlılıklarına göre değişir (Büyüköztürk vd. 2008). Şimşek ve Yıldırım'a (2006) göre, araştırmanın amacı belli bir ortam ve belli bir süreçteki sosyal olayların incelenmesi olduğu için, çalışmanın aynen yinelenebilmesi olanaksızdır. Bu nedenle, nitel araştırmalarda her ortam için geçerli kurallar ve standartlar geliştirmek mümkün değildir. Yapılan her araştırma, yapıldığı ortam ve kişilerle sınırlıdır. Nitel araştırmalar gerçek yaşamın sürekli değişkenliği nedeniyle aynen tekrarlanamaz ve kopya edilemez. Glesne ve Peshkin (1992), araştırma sürecinde elde edilen verilerin ve oluşturulan bulguların iyi tanımlanması halinde bu alanda çalışacak diğer araştırmacılara yardımcı olacağını, çalışılan alandan elde edilen notların, görüşme kopyalarının, araştırmacının verileri yorumlamak için geliştirdiği kodlamaların ayrıntılı bir şekilde betimlenmesinin araştırmanın niteliği açısından faydalı olacağını belirtmişlerdir. Hammerssley'e (1998) göre yapılan bu nitel çalışmalar, o alanda incelemelerde bulunan diğer uygulayıcıların karşılaştıkları problemlere uyarlanmasında çözümler sunabilmelidir.

Yapılan araştırmada verilerinin toplanabilmesi için iki adet ölçü aracı geliştirilmiştir. İlki, görüşme yapılan kişilerin demografik bilgilerinin yer aldığ 1 bilgi formu, diğeri ise yarı yapılandırılmış görüşme sorularıdır. Yarı yapılandırılmış görüşme tekniğinde, araştırmacı önceden sormayı planladığı soruları içeren görüşme protokolünü hazırlar. Buna karşın araştırmacı görüşmenin akışına bağlı olarak değişik yan ya da alt sorularla görüşmenin akışını etkileyebilir ve kişinin yanıtlarını açmasını ve ay- rıntılandırmasını sağlayabilir. Yarı yapılandırılmış görüşme tekniği, yapılandırılmış görüşme tekniğinden biraz daha esnektir. Bu görüşme tekniği, nitel araştırma içerisinde görülebilir (Ekiz 2003). Yarı yapılandırılmış görüşme tekniğinin araştırmacıya sunduğu en önemli kolaylık görüşmenin önceden hazırlanmış görüşme protokolüne bağlı olarak sürmesi nedeniyle daha sistematik ve karşılaştırılabilir bilgi sunmasıdır (Şimşek ve Yıldırım 2006). Yarı yapılandırılmış görüşmelerde bir araştırmacı, karşılaştırmalı veriler topladığına dair güven içindedir. Ancak, bu durumda kişilerin belli bir konuyu nasıl yapılandırdıklarını görme şansını yitirme durumu söz konusu olabilmektedir (Özdamar vd. 1999).

Araştırmada kullanılan yarı yapılandırılmış görüşme formunun geçerliliği için çeşitli ölçütler bulunmaktadır. Bunlardan biri katılımcı teyididir. Bu noktada belirlenen kuruluşların temsilcilerin seçiminde gönüllülük esas alınmış ve sorulara içten yanıt vermelerini sağlamak için isimlerinin gizli tutulacağ 1 ve hiçbir şekilde açıklanmayacağı belirtilmiştir. Şimşek ve Yıldırım (2006), katılımcıların gönüllü olmalarının araştırmanın geçerliği ve güvenirliğini sağlama açısından önemli olduğunu vurgulamaktadır. Bundan dolayı temsilcilerin araştırmaya gönüllü katılmalarını sağlamak için temsilcilere araştırmanın önemi ve kendilerinin sunacakları katkı anlatılmıştır. İkinci ölçüt ise verilerin katılımcılar ile yüz yüze derinlemesine görüşülerek toplanmasıdır. Bunun için araştırmacılar ile yüz yüze görüşmeler yapılmış ve veriler bu yolla toplanmıştır. Bir diğer ölçüt de ortaya konan görüş ve önerilerin araştırma konusuna ilişkin ana temaları açıklayıcı ve yorumlayıcı bir niteliğe sahip olmasıdır. Bu doğrultuda temsilcilerin bu alanda yaşanan sorunlara ve çözüm önerilerine ilişkin açık bir yorum getirmeleri için uygun ortam oluşturulmuştur. Bütün bunların araştırmanın iç geçerliliğini kanitlayan ölçütler olduğu kabul edilmektedir.

Görüşme formunun uzman görüşüne sunularak teyit edilmesi de araştırmanın güvenirliğini sağlayan önemli bir ölçüttür. Bu çerçevede konu ile ilgili olarak üniversitede özel eğitim bölümünde görevli bir engelli eğitim uzmanı akademisyen ve turizm bölümünde görevli iki akademisyen ile engelli ve engelliler için faaliyet gösteren sivil toplum örgütünün iki temsilcisinin görüşlerine başvurulmuştur. Güvenirliği sağlayan bir diğer ölçüt ise katılımcıların görüşlerinin bulgular kısmında doğ- 
rudan aktarım yoluyla gösterilmesidir. Bunun için temsilci görüşleri aynen olduğu gibi aktarılmıştır. Soruların temsilcilerin anlayabileceği açıklık ve belirginlikte olmasına; karmaşık, anlaşılması güç olmamasına ve yanlış anlamaya yol açmayacak nitelikte olmasına dikkat edilmiştir. Bu yolla toplanan verilerin geçerlik ve güvenirliğinin olumsuz yönde etkilenmesi engellenmeye çalışılmıştır. Araştırmada, yukarıda yer alan altı alt amacı ölçmeye hizmet edecek şekilde engellilerin tatil olanakları, tatil tercihleri, ihtiyaçları, ihtiyaçlarının karşılanma düzeyi, sorunlar ve öneriler temelinde yapılanmış 8 adet açık uçlu soru hazırlanmıştır.

Görüşmeler katılımcılarla önceden belirlenen gün ve saatlerde görevli oldukları kurumlarda kendi belirledikleri mekânlarda yüz yüze görüşmeye dayalı ve bire-bir olarak yürütülmüştür. Görüşme sırasında katılımcının izni doğrultusunda ses kaydı yapılmıştır. Görüşmelerden il dışındakiler 04.05.2012 tarihinde, Antalya'da gerçekleştirilenler ise 06.06.2012 tarihinde yapılmıştır. Görüşmeler, projenin engelli eğitim uzmanı olan bu çalışmanın ikinci yazarı tarafından gerçekleştirilmiştir.

\section{Nitel Araştırma Verilerinin Toplanması ve Analizi}

Akdeniz Bölgesi'nde engelli STK'ları temsilcileri, Kültür ve Turizm İl Müdürlügü ve Aile ve Sosyal Politikalar İl Müdürlüğü yöneticileri ile görüşmeler planlanmıştır. Araştırmada katılımcıların seçiminde, araştırma amacına uygun olarak erişilebilir turizm kapsamında hem arz hem de talep cephesinden temsilcilerin görüşlerinin alınmasının yararlı olacağı düşünülmüş ve bu nedenle amaçlı örnekleme yoluna gidilmiştir. Araştırma verileri yari-yapılandırılmış görüşme tekniğiyle toplanmıştır. Görüşmelerden elde edilen veriler dört aşamada betimsel analiz tekniği ile analiz edilmiştir. Betimsel analiz, çeşitli veri toplama teknikleri ile elde edilmiş verilerin daha önceden belirlenmiş temalara göre özetlenmesi ve yorumlanmasını içeren bir nitel veri analiz türüdür. Bu analiz türünde araştırmacı görüştüğü ya da gözlemiş olduğu bireylerin görüşlerini çarpıcı bir biçimde yansıtabilmek amacıyla doğrudan alıntılara sık sık yer verebilmektedir. Bu analiz türünde temel amaç elde edilmiş olan bulguların okuyucuya özetlenmiş ve yorumlanmış bir biçimde sunulmasıdır (Şimşek ve Yıldırım 2006). Görüşmeye dayalı nitel araştırma veri- lerinin analizinde, ses kayıtlarının yazıya dökülmesi, dökümlerin doğruluğunun kontrol edilmesi, görüşme indekslerinin oluşturulması ve güvenirlik çalışmasının yapılması önemli aşamalardır (Kvale 1996). Araştırmada kullanılan betimsel analiz sürecinin aşmaları ve her bir aşamada yapılan işlemler şöyle özetlenebilir:

\section{Analiz Öncesi Hazırlık}

Bunun için öncelikle yarı-yapılandırılmış görüşme sonrası ses kayıtları bilgisayar ortamında yazıya aktarılmıştır. Ses kayıtlarının doğruluğu dökümler üzerinde kontrol edilmiştir. Araştırmacılar bu kontrol işlemini birbirlerinden bağımsız olarak yapmışlardır. Analiz sürecinde kullanılan görüşme dökümü formu, bağlamsal bilgiler, betimsel indeks, betimsel veri, görüşmeci yorumu ve genel yorum bölümlerinden oluşmaktadır.

\section{Veri Eşleştirme}

İlk aşamada oluşturulan betimsel indeks bölümündeki veriler gruplandırılarak ilgili olduğu görüşme sorusu altında eşleştirilmiştir. Görüşme soruları tema olarak kabul edilmiştir. Görüşme kodlama anahtarının oluşturulmasında, katılımcıların her bir soruya verdikleri yanitların bulunduğu betimsel indeks bölümü esas alınmıştır. Daha sonra, araştırmacılar bir araya gelerek kodlama anahtarlarındaki eşleştirmeleri gözden geçirmiştir. Yeniden okuyarak yapılan inceleme sonrasinda her bir sorunun altına girebilecek yanit kategorileri yazılarak "Görüşme Kodlama Anahtarı" oluşturulmuştur. Bulguların tanımlanması için nitel veriler sayısal verilerle ifade edilmeye çalışılmıştır. Bulguların yorumlanması için veriler, görüşme sorularının s1rasıyla verilmiş, ilişkilendirilmiş, doğrudan alıntılarla bulgular desteklenmeye çalışılmıştır. Uygun olmayan eşleştirme varsa, uygun olduğu temayla ilişkilendirilmiştir.

\section{Veri Sınıflandırma}

Veri eşleştirilmesi aşamasında elde edilen sonuçlara göre katılımcıların görüşleri sınıflandırılmıştır. Bir önceki aşamada görüşme sorularına dayalı temaların altında oluşturulan alt temalar gözden geçirilmiştir. Engellilerin tatil olanakları, tatil tercihleri, tatil organizasyonundan gerçekleştirilene kadar olan gereksinim ve talepleri, taleplerin ger- 
çekleşme düzeyi, sorunlar, ilgililere düşen görevler ve öneriler olmak üzere altı ana tema çerçevesinde sorular yöneltilmiştir. Sorulan sorulara verilen yanitlar her bir sorunun altına gelecek şekilde tema ve alt temalar kesinleştirildikten sonra, verilere son biçimi verilmiş ve veriler düzenlenmiştir.

\section{Veri Analizi}

Veri sınıflandırma aşamasında belli temalar altında kodlanan katılımcı görüşlerinden hangilerinden doğrudan alıntı yapılacağına bu aşamada karar verilmiştir. Böylece, bu aşamada katılımcıların belirtikleri görüşler arasında bağlantılar kurulmuş ve görüşleri destekleyen alıntılar yapılmıştır. Bu işlemlerden sonra analiz işlemine son verilerek araştırma bulgularının yazımına geçilmiştir.

Yukarıda belirtilen analiz sürecinin her bir aşaması iki araştırmacı tarafından ayrı ayrı yapılmıştır. Ayrıca, araştırmada inanılırlığı sağlamak amacıyla farklı işlemler yapılmıştır. Bunlar; verilerin öncelikle yorumsuz olarak sunulması, verilerinin analizini birden fazla araştırmacının yapması, verilerin analizinde sürekli karşılaştırma yönteminin benimsenmesi ve verilerin analizinde kuramsal çevreye bağlı kalınması biçiminde sıralanabilir (Lincoln ve Guba 1985; Freeman vd. 2007).

\section{Nitel Araştırma Bulguları}

Akdeniz Bölgesindeki engelli STK'ları, Turizm Müdürlükleri ve Aile ve Sosyal Politikalar İl Müdürlüklerinde görevli toplam 12 kişiyle (katılımcıyla= K) görüşülmüştür. Bunlardan altısı engelliler ile ilgili STK yetkilisidir. Her üç ilde de mevcut olup engellileri temsil edecek ve veri alınabilecek kamu ve STK birimleriyle önceden randevu alınarak görüşülmüştür.

\section{Katılımcılara İlişkin Demografik Göstergeler}

Görüşmenin hemen öncesinde katılımcılardan bir bilgi formu doldurmaları istenmiştir. Bilgi Formu ile katılımcıların öğrenim düzeyi, görev süresi, varsa engeli, yaşantısında engelli kişi olup olmadığı, varsa yakınlığı, en az bir kez engelli biriyle iletişime geçip geçmediğine ilişkin bilgilere ulaşılmaya çalışılmıştır. Katılımcıların başlıca demografik özellikleri Tablo 1'de verilmiştir.

Katılımcıların dördü engelli olup bunların ikisi görme engelli, diğer ikisi ise bedensel yetersizliğe sahiptir. Yaşantısında (kendisi dışında) engelli bireyler olup olmadığına ilişkin sorulan soruya beş kişi evet cevabını vermiştir. Bunlardan ikisinin zihinsel, üçünün ise bedensel yetersizliği olduğu belirtilmiştir. Bu kişilerin dişında kalan, yaşantısında engelli kişi olmadığını bildiren yedi kişiden beşi hayatında en az bir kez engelli bir bireyle iletişime geçtiğini, iki kişi ise hiç iletişime geçmediğini bildirmiştir. Dolayısıyla 12 katılımcıdan ikisinin engelli bir kişiyle bir kere bile olsa iletişime geçmediği görülmektedir.

\section{Engellilerin "Tatil Yapma Olanaklarına" İlişkin Katı-} lımcı Görüşleri (Amaç 1)

Yapılan görüşmelerde ilk olarak "görme/işitme/ bedensel engellilerin tatil yapma olanaklarından bahseder misiniz?" sorusu yöneltilmiştir. Katılımcilardan yedisi mimari engellerden dolayı engellilerin istedikleri gibi bir tatil yapamadiklarını, dört katılımcı olanakları olmadığını, üçü ise maddi imkânsızlıklar nedeniyle tatile çıkamadıklarını belirtmiştir. İki katılımcı ise tatil yapma olanağı olan kişilerin de tek başlarına değil, mutlaka refakatçileriyle birlikte tatil yapmak zorunda olduklarını ifade etmiştir. Bir katılımcı engelli kamplarına gittiğini, diğer bir katılımcı çevredekilerin tutumundan, bir diğer katılımcı da yabancı turistlerin çokluğundan olumsuz yönde etkilendiğini dile getirmiştir.

Engellilerin tatil yapma olanaklarına ilişkin bazı katılımcıların görüşleri şöyledir:

K6. “...Alana gidip onları komisyonla evde de ziyaret etme zorunluluğumuz var. Özürlüyü ve bakan kişiyi görme, yaşadı̆̆ı ortamı görme. Yerinde de değerlen-

Tablo 1. Katılımcıların Demografik Özellikleri (K=12)

\begin{tabular}{llr}
\hline & Özellikler Grup & $($ K) Katılımcı Sayısı \\
\hline Cinsiyet & Kadın & 5 \\
& Erkek & 7 \\
\hline Öğrenim durumu & Yüksek Lisans & 2 \\
& Lisans & 6 \\
& Lise & 1 \\
& Ortaokul & 3 \\
\hline Hizmet yılı & $0-5$ Yıl & 2 \\
& $6-10$ yıl & - \\
& $11-15$ yıl & 3 \\
& $16-20$ yıl & \\
& 20 yıl ve üzeri & 4 \\
\hline Kendisinde engel olma durumu & 8 \\
\hline & Var & \\
& Yok & \\
\hline
\end{tabular}

Cilt 26 
dirdiğimizde bu kişilerin aile yapıları orta ve alt sosyoekonomik düzey grubuna girendir. Yani eve giren her türlü geliri evde yaşayan kişi sayısına böldügüumüzde 420 liranın altında kişi başına düşen rakama ulaşanlar ki bu kişilerin tatil şanslarının olduğunu pek düşünmüyorum."

K8. "Ben aslında en çok şeyi düşündüm siz sorduğunuzda, kişilerden çok bu kişileri bakan kişileri yani o bakıcılar bankaya gidemiyorlar. Belediyeye fatura ödemeye gidemiyorlar. Sosyal hayatları sıfırlanmış durumda. Kapı komşuları onlara geliyor ama onlar evden d1şarıya çıkamıyorlar. Aslında evet bakanların tatile daha çok ihtiyacı var."

K11. “Görebildiğim kadarıyla çok fazla böyle bir imkâna sahip olmadıklarını düşünüyorum. Mesela diyelim ki ailede çocuğu engelliyse işte mümkün olduğunca zor şartlarda yani tatile çıkmada sıkıntı yaşadıklarını düşünüyorum ben gittikleri yerlerde. Çünkü bu imkânları bulamayabiliyorlar ya da orda bir hoşgörüyü bulamayabiliyorlar. İște görme engellilerin zaten kendileri bizatihi annesi, babası ya da yakınının desteği olmadan hareket etmesi mümkün değil..."

Engellilerin "Tatil Tercihlerine" İlişkin Katılımoı Görüşleri (Amaç 2)

Katılımcılara engellilerin tatil tercihlerine yönelik olarak "Tatil imkânına sahip olan görme/işitme/ bedensel engelli bireyler ne tür tatil yapmayı tercih etmektedir? Nasıl bir tatil onları mutlu eder?" soruları yöneltilmiştir. Bu sorulara katılımcıların dokuzu fiziki koşulların sağlanması durumunda her türlü tatil şeklinin onları mutlu edeceğini, sağlıklı insanlardan farklı şekilde tatil yapmayı tercih etmeyeceklerini belirtmiştir. Bir katılımcı termal kaplıca turizmini, bir katılımcı bakanlıktan belgeli her şey dâhil hizmet veren büyük otelleri ve bir katılımcı da grupça gitmeyi tercih ettiklerini belirtmiştir.

Katılımciların bu soruya verdikleri yanitlardan bazıları aşağıda verilmiştir:

K3. "Tatil yapmada tercihleri fiziksel koşullar ile orantılıdır. Kişi çok fazla hareketli değil tekerlekli sandalye kullanıyor ise ki bizim gurubun çoğunluğu böyledir. Otelin içinde rahat hareket edebileceği, daha aktif olacağı, gezebileceği alıșveriș edebileceği, oteldeki etkinliklerin kullanılabildiği ve ailemiz ile gidebileceği tatilleri tercih ediyoruz."

K1. "Ben şöyle düşünüyorum, biz insanoğlu doyumsuz kişileriz. Birlikte hareket edilen bütünlü bir organizasyonda deniz tatili de olabilir, kır tatili de olabilir veya da turizme açık tatil yöreleri var, örneğin Pamukkale. Hepsi de onları tatmin eder. Belki tek olarak bireysel olarak gitseler o kadar tatmin etmez ama grup olarak gittikleri için onları çok güzel tatmin eder. Birbirlerini motive etmiş olurlar diye düşünüyorum."
K8. “...o anlamda tatil seçenekleri açısından deniz tatili isterler işte kayak tatili, kar tatili diye bir ayrım yapabileceklerini zannetmiyorum. Onlar için nefes almakla eş değer olacağı için hangi mevsimde ve nereye gittiklerinin çok büyük bir önem taşıdığını düşünmüyorum. Hani soluk alacaklar çünkü."

K9. "Ben sağlıklı birey grubunda bir kadın olarak nasıl bir tatil yapmak istersem herhalde engelli olan kardeşim de aynı talepleri dile getirecektir, o da denize gitmek isteyecektir, o da dağa tırmanmak isteyecektir, o da özgürce koşmak yürümek isteyecektir. Ne yapmak istiyorsa yapmak isteyecektir. Kitap okumak isteyecektir bunların hepsi bir hak. Engelli şöyle tatil yapar, bunu yapsin yeter bunu kabul etmiyorum. Ben ne istiyorsam aynı onun da kișisel seçme hakkı vardır. Dayatılamaz. ...Ben nasıl sağlıklı bir birey olarak tatil yapmak istiyorsam engelli de aynı şekilde o da seçimleri vardır. Bize sağlanan koşullar onlara da sağlanmalıdır. İki gün sonra vazgeçmem herhalde alıştığım tesise gitmekten, ayağımda bir sakatlık meydana gelse veya görmemde bir sorun olsa ben zevk aldığım sahilde yüzmeye devam etmek isterim. Kimse sen artık burada yüzme, biz sana burayı yaptık git orada suya gir çık demesin bunu istiyorum. Ben neyi istiyorsam onlara da o olsun"

Engellilerin "Tatil Organizasyonu, Seyahat ve Konaklama Süreçlerindeki Taleplerine" İlişkin Görüşler (Amaç 3)

Engellilerin tatil öncesi ve sonrasında taleplerinin neler olabileceğine ilişkin soru yöneltilmiştir. Katılımcılar, "Tatil organizasyonu için bulundukları yerden, gittikleri kuruluşlara, tatil yöresine ve tatil binasına erişimleri ve tatil ortamı içinde hareketlilikleri açısından düşündüğünüzde engellilerin ne tür talepleri olmaktadır ya da olabilir?" sorusunu yanıtlamışlardır. Katılımcıların verdikleri yanıtlar ve dağılımı Tablo 2'de verilmiştir.

Katılımcıların engellilerin tatil taleplerine ilişkin görüşleri, araştırmanın hedef kitlesi olan görme, işitme ve bedensel engelliler ve genel kategorileri altında incelenmiş ve her bir kategoriye giren yanıt seçenekleri gruplanmıştır. Buna göre görme engelliler için ifade edilen taleplerden en fazlası altı katılımcı ile oda ya da asansörlerde sesli uyarı sistemleri olmuştur. Altı katılımcı, bedensel engelliler için en çok mimari düzenlemeleri, bir katılımcı işitme engelliler için işaret dili bilen eleman talebini, bir katılımcı ise görsel uyarıcıları ifade etmiştir. Tüm grupları ortak etkileyen durumların gruplandığ genel kategorisinde ise dört katılımcı yanlarına refakat edecek yardımcı personele ihtiyaç duyduklarını belirtmiştir. Bu konuda katılımcılardan bazılarının görüşlerine aşağıda yer verilmiştir: 
Tablo 2. Engellilerin Katılımcı Görüşlerine Göre Tatil Organizasyonu Kapsamlı Talepleri

\begin{tabular}{llr}
\hline Engel Türü & Katılımcılara Göre, Engelli Tatil & K. Sayısı \\
& Organizasyonu Talepleri & \\
\hline Görme & Oda ya da asansörlerde sesli & 6 \\
Engelliler & uyarı sistemleri & \\
& Kabartma yazılı materyaller, levhalar, & 2 \\
& yönlendiriciler & 1 \\
& Engelsiz internet & 12 \\
\hline Dokunsal uyarıcılar & \\
& Standartlara uygun mimari & 6 \\
Engelliler & düzenlemeler & 1 \\
& Özel transfer aracı & 1 \\
\hline İşitme Engelliler & İşaret dili bilen eleman & 4 \\
& Görsel uyarıcılar & 1 \\
\hline \multirow{2}{*}{ Genel } & Rehber/refakatçi/yardımcı personel & 1 \\
& Engelsiz oda dekorasyonu & 1 \\
\hline & Maddi destek &
\end{tabular}

K12. “...Her şey dâhil olan Bakanlığımızdan belgeli büyük otellerde sıkıntı olmuyor. Asıl sıkıntı uçaktan otele kadar olan kısım. Tur operatörlerinin acentelerinin yeni getirttikleri asansörlü olan otobüslerden ne yazık fazla yok sadece birkaç tane var. Tabi bu anlamda çok talep var. Engelli bir birey Antalya havaalanına geldi diyelim, tur operatörünün karşılama imkânı yok ise ya da otele geldi, tarihi yerleri görmek istiyor. Yani tarihi yerleri görmek isteyen bireylerde çok şehir merkezine indi diyelim, șehir merkezinde alıșveriș merkezlerinde kaldırımlarda engelli rampalar istiyorlar. Tarihi yerlerde șehir merkezlerinde gezileri anlamında rahat etmek istiyorlar. Genelde refakatçi ile geldikleri için sorun çıkmıyor halkımız da çok misafirperver ve çok güler yüzlü sadece bizim halkımız değil insanoğlu yardım ediyor."

K4. “Evden çıkıp nereye gitmek istiyorsa bunların sağlanması gerekiyor. Evden sağlıklı olarak çıkabilmesi gerekiyor. İletişim kaynaklarıyla sağlıklı tatil imkânlarını görebilmesi lazım, şu anda daha kolay, internetimiz bilişim sistemlerimiz var, bunlar gelişti evimizde bunları bir tık ile yapabiliyoruz ama görme engellilerin içinde aynı şekilde teknik donanıma sahip araçların da olması gerekiyor. Hadi bunları da temin ettik diyelim. Evden çıacak şirketlere ulaşacak evden çıkarken rampası küçük asansörleri kendisini bu bölüme taşıyacak araçlar olacak. ......Transferinden uçakta yer ayrılmasından, sırasından, bilet almasından, bilgilendirilmesinden görmeyen vatandaşımız için bunu çok iyi tasarlayacak anlayışın olması gerekiyor. Kabartma falan kullanılabilir belirli materyallerin kullanılması gerekiyor bunlar da çok önemli, biz görüyoruz onların da bunu hissetmesi gerekiyor. ...Evden çıkamadıktan sonra tatile gidebilme imkânı nasıl olabilir ki yeni yeni büyük şehirlerde engelliler için engelli taksileri, otobüslerin rampalı olanları oluşturuldu..."

“... tabi başlangıçta işitme engelli dilinden, işaret dilinden anlayan genelde yetişmiş elemana ihtiyaç var.
Siparişleri alacak garsondan tutun rezervasyonu yapacak görevliye kadar. Orda bu desteğe ihtiyaç var. Tabi ki de yabancı dil bilen resepsiyon görevlisine olacağı gibi. ...Oralarda yine kaldırımlardaki sinyalizasyon gibi asansör yapılarını buna uygun şekilde sesli komutlarla olması düşünülebilir. Odada telefonu kullanabiliyor, görme engelliler ama işitme engelliler sipariş alacağ 1 zaman onlar da başka bir iletişim dilleri var mı bilmiyorum...."

Engellilerin "Tatil Organizasyonu, Seyahat ve Konaklama Süreçlerinde Karşılaştıkları Sorunlara" İlişkin Görüşler (Amaç 4)

Katılımcılara yöneltilen "Sizce mevcut turizm hizmetleri, görme/işitme/bedensel engellilerin bu taleplerini ne düzeyde karşılayabilmektedir?" sorusunu 10 katılımcı mevcut turizm hizmetlerinin engellilerin gereksinimlerini karşılamadığı yönünde yanıtlamış, ancak farklı sorun alanlarını da dile getirmiştir. Altı katılımcı mimari düzenlemeler konusundaki sorunlardan bahsetmiştir. Bunlar arasında, bina girişlerindeki rampaların yüksek eğimli olması ya da hiç rampanın olmaması, kaldırımların yüksekliği, engelliye saygılı mimarinin olmayışı şeklinde görüşler yer almıştır. Dört katılımcı transfer için kullanılan araçların bedensel engellilerin gereksinimine uygun olmadığını belirtmiştir. Katılımcılardan ikisi olumsuz tutumlardan, ikisi eğitim eksikliğinden ve ikisi de işaret dili bilen elamanların olmayışından bahsetmiştir. Bir katılımcı engelli turizminin pazar olarak görülmemesini, bir katılımcı dokunsal işaretçilerin yetersizliğini ve diğer bir katılımcı da düşük geliri sorun olarak belirtmiştir.

Bazı katılımcının bu konudaki görüşleri şu şekildedir:

K5. “Karşılayamıyor. Yeterli değil. Yani şu anda hala biz özürlüyü çok iyi kabul etmiş değiliz. O nedenle belki toplum olarak fiziksel çevre düzenlemesi olsun, olanaklar olsun yeni yeni düzenleniyor diye düşünüyorum".

K2. “Ben kesinlikle karşılandığını düşünmüyorum. Yeni yeni adımlar var ama çok yetersiz. Engelliler için yapılan organizasyonda bilgi yetersizliği var birçok firma kontenjan ayırmıyor, engellileri düşünmüyorlar. Çünkü gelir düzeyleri düşük ve talep yok".

K7. "Engelliyi tatile getiren firmalar transferi yaptıklarında tatil ihtiyaçlarını karşılanmış sayıyor. Havaalanından alıp otele bırakmak ve otelden alıp havaalanına bırakmak ile tatil organizasyonu tam anlamı ile yapılmıyor. ...Turizm Bakanlığı'nın belirlemiş olduğu oda sayısı, kotası var, otel o kotayı doldurmak için oda yapıyor. Paranızla süit odada kalma imkânınız yok. Odalarında alanı geniş tutarak tutunma barı yapılması ile 
daha kullanışlı hale getirilebilir odalar ama bir oda bu şekilde düzenleniyor, bu kota otelin müşteri kaybetmesine neden oluyor".

K1. "Ama bizim bir de öncelikle dile getirmemiz gereken konu karayolu taşımacılığında bedensel engelli vatandaşların maalesef yani onlara yönelik hiç bir çalışmaları yok. Ben kendim dokuz sene oldu kazayı yapalı. Bir yıllığına alletraksiyon aleti takınarak devam ettim. ... sarsıntıdan vidalar batıyor. ... diyorsun ki işte benim durumum bu, raporum var, rahatsizım diyorsun firma sahiplerine, mümkünse önden yer.. İşine gelirse boş yerimiz yok..."

Engellilerin tatil yapabilmelerini sağlamak için "turizm aracılarına, engelli STK'ya ve devlete düşen görevlere" yönelik görüşler (Amaç 5)

Katılımcılara "Görme/işitme/bedensel engellilerin tatil yapabilmelerini sağlamak için turizm aracılarına, engelli STK'ya ve devletin ilgili organlarına düşen görevler konusunda ne düşünüyorsunuz?" sorusu yöneltilmiştir. Katılımcılar turizm aracıları, engelli STK ve devletin ilgili birimleri için düşüncelerini belirtmişlerdir. Katılımcıların bu soruya verdikleri yanıtlara Tablo 3'te yer verilmiştir.

Katılımcılardan ikisi, grubun özelliklerine göre hizmetlerin düzenlenmesi ve donanımların güçlendirmesini, turizm aracılarının görevleri arasında belirtmişlerdir. Bunun yanında birer katılımcı da turizm aracilarının engelliler konusunda otelleri bilgilendirmesi, otelleri engellilere yönelik hizmetler konusunda zorlaması, onları doğru yönlendirmesi, engelli dostu otellerle işbirliği yapması gerektiğini belirtmiştir. Ayrıca turizm aracılarının engelliler konusunda kendini yetiştirmesi gerektiğini ifade etmişlerdir.

Engellileri temsil eden sivil toplum kuruluşlar1nın yapması gerekenlere ilişkin olarak ise beş katılımcı temsil ettikleri grubun ihtiyaçlarını, sorunlarını ilgililere bildirmesi gerektiğini belirtmiştir. İki katılımcı ise denetlemeye katılmaları, sorunları direkt yerinde tespit etmelerini sağlayacaktır, şeklinde görüş bildirmiştir. Bir katılımcı toplumda engelli bilinci oluşturmaya yönelik çalışmalar, diğer bir katılımcı ise temsil ettikleri gruplar için turizm etkinlikleri organizasyonu yapmaları gerektiğini ifade etmiştir.

Aşağıda bazı katılımcı görüşlerine yer verilmiştir:

K7. "Tur operatörlerinin engellilere özel getirdiği asansörlü transfer araçlarının yaygınlaştırılmalıdır. Ayrıca
Tablo 3. Engellilerin Tatil Yapabilmeleri İçin Taraflara Düșen Görevler

\begin{tabular}{llr}
\hline & Görevler & K. Sayısı \\
\hline Turizm aracıları & Grubun gereksinimlerine göre & \\
& hizmetleri, donanımı güçlendirme & 2 \\
& Otelleri bilgilendirme & 1 \\
& Otelleri zorlama & 1 \\
& Doğru yönlendirme & 1 \\
& Engelli dostu otellerle işbirliği & 1 \\
& Bu konuda kendini yetiş̧irme & 1 \\
\hline Engeli STK & Yaşadıkları sorunları, ihtiyaçları bildirme & 5 \\
& Denetlemeye katılım & 2 \\
& Toplumda engelli bilinci oluşturma & 1 \\
& Organizasyon & 1 \\
\hline Devletin İlgili & Engelliye tatil için maddi destek & 4 \\
Birimleri & Vergi indirimi & 2 \\
& Fiziki düzenlemeler için cezai yaptırım & 1 \\
& Belediyeleri destekleme & 1 \\
& Fiziksel çevre düzenlemeleri & 1 \\
\hline
\end{tabular}

yasal olarak zorunlu hale getirilmesi gerekiyor. Tipk 1 otellerdeki engelli odaları tuvaletleri, asansörler, bakanlık tarafından nasıl zorunlu tutulmuşsa, böyle bir düzenleme yapılabilir".

K4. “Bütün STK'lara görev düşüyor. Özellikle engelli gurupları temsilen kurulmuş olan STK'lar hakların ve işlemlerin takipçisi olabilirler, kendilerini rahat anlatabilecekleri onların ihtiyaçlarını kamuoyunun daha sağlıklı duymasını sağlayabilirler. Ben bir görme engellinin ne zorluklar yaşadığını anlamam, istediğim kadar duygudaşlık yapayım anlamam mümkün değil. İşitme engellinin durumunu anlayamam bu alanda duygudaşlık yapılamaz, sadece daha duyarlı davranılabilir. Özellikle STK'lar bu duyguyu aktarmaları gerekir. Bütün STK'ların turizm içindeki stoklardan hizmet kalitesinin artırılması için bir hizmet yarışı oluşturabilirler".

K2. “Devlet engellilere tatil amaçlı yaptırımlar yaratması lazım, örneğin turizmle ilgili sektörlere finans sağlayabilir. Engellilere turizmden faydalanabilmesi için ödenek çıkarılabilir. Fiziki ortamlar için yaptırımlar uygulanabilir, ceza yaptırımı gibi. Engelli ve hükümlü yasalarından bir fona para akıyor, o fon ile proje sunulabilir, istendiği takdirde olmayacak bir şey yok".

K3. "Devlet sadece engelli bireyler için tatil düzenlemesi yapması zor geliyor ama tatil yapma hakkı herkese verilmiş ise devlet destek sağlamalı, ama birey dört kişilik ailesi ile tatile gidiyor. İçlerinden sadece engelli bireyin tatilini desteklemesi bir çözüm değil. Gelir düzeyi tatile elverişli olmayanları desteklenmeli".

Engellilerin Turizm Hizmetlerinden Yararlandırlması Önerileri (Amaç6)

Katılımcıların engellilerin turizm hizmetlerinden yararlanmasına yönelik önerilerini alınmak isten- 
miştir. Bunun üzerine "Görme/işitme/bedensel engellilerin turizm hizmetlerinden yararlanmasinın sağlanmasına yönelik ne tür önerileriniz bulunmaktadır?" sorusu yöneltilmiştir. Katılımcılar, önerileri aşağıdaki gibi belirtmişlerdir.

Katılımcılardan beşi bu soruya engellilerin refakatçileriyle birlikte maddi olarak desteklenmesi durumunda daha fazla tatil yapma isteğinde olacaklarını belirtmiştir. Yine beş katılımcı çeşitli fiziki ve mimari engellerin ortadan kaldırılması gerektiğini, iki katılımcı işletmelere teşvikler uygulanabileceğini ve diğer iki katılımcı ise toplumda engellere yönelik farkındalık yaratılması gerektiğini ifade etmişlerdir. Bir katılımcı, devlete bağlı kurumların yazlık kamplarının engellilerin kullanımına açılabileceğini, diğer bir katılımcı yurtdışındaki gibi engellinin yanında refakat edecek hemşirelerin görevlendirilmesini önermiştir. Bir katılımcı ise sivil toplum kuruluşları, turizm işletmecileri ve devletin kurumları ile üniversitelerin ortak akıl yürütmesinin faydalı olacağını belirtmiştir. Bir katılımcı ölü sezonların kullanabileceğini, bir katılımcı ise otellere verilen engelli odası oranının artırılmasının faydalı olacağını belirtmiştir.

\section{ARAŞTIRMA SONUÇLARI, TARTIŞMA VE ÖNERILER}

Katılımcılara yönlendirilen altı araştırma sorusu ile onların engellilerin tatil olanakları, tatil tercihleri, ihtiyaçları, ihtiyaçlarının karşılanma düzeyi, sorunlar, ilgililere düşen görevler ve önerilere ilişkin görüşlerinin derinlemesine incelenmesi amaçlanmıştır. Araştırmada görüşleri alınan Turizm İl Müdürlüğü, Aile ve Sosyal Politikalar İl Müdürlügü ve engelli STK'ları temsilcilerinin ikisi hariç diğerlerinin ya kendinde ya da yaşantısında engelli bireylerin bulunduğu, dolayısıyla bir şekilde en az bir kez engelli bireyle karşılaştıkları görülmektedir.

Katılımcıların, engellilerin tatil olanaklarının olmadığına dair görüşleri bulunmaktadır. Büyük kısmının maddi açıdan güçlük içinde olduğu ve tatili düşünecek durumda olmadıkları belirtilmiştir. Katılımcıların birçoğu tatil olanağı olan engelli birey ve ailelerinin ise tatil tercihlerinin herkes gibi değişebileceği, fiziki koşulların sağlanması durumunda her türlü tatilin onları mutlu edebileceği yönünde görüş bildirmiştir. Erişilebilir turizm üzerine yaptığı çalışmalarla turizm alanyazınında önemli bir etkiye sahip olan Darcy de (1998) elde edilen bulgulara benzer görüşleri öne sürmektedir. Darcy'ye (1998) göre, engellilerin turizm faaliyetlerine katılmasına engel oluşturan etkenlerin başında ekonomik sorunlar gelmektedir. Bunun dışında kişilerin fiziksel olarak bağımsız hareket edememeleri, uygun konaklama işletmeleri bulamamaları, gidecekleri yer ve bölgelere ulaşımda yaşanan teknolojik yetersizlikler (otobüs ve taksilerin uygun düzenlenmemesi) diğer önemli engeller olarak ifade edilmektedir.

Tatil organizasyonundan tatilin gerçekleştirilmesi aşamasına kadar engellilerin taleplerinin ne olabileceğine dair görüşler arasında en fazla fiziki koşullar konusunda talepler bildirilmiş, bunun yanında refakatçi ihtiyaçlarının olacağına dair görüşler de yer almıştır. Nitekim Öztürk vd.nin (2008) araştırmasında da benzer şekilde engellilerin taleplerinin fiziki koşulların iyileştirilmesi yönünde görüşler olduğu bildirilmiştir. Araştırmacılar, otel ve seyahat acentesi yöneticilerine yönelik olarak uyguladıkları ankette bedensel engellilerin ihtiyaçlarının karşılanma durumunu belirlemeyi amaçlamıştır. Yöneticilerin bu konudaki görüşleri arasında çevresel koşulların eksik olduğu, otellerin en çok merdiven, banyo ve tuvaletlerinde sıkıntı yaşandığ 1 ifade edilmiştir. En sık bahsedilen bir diğer sorun ise transfer araçlarının uygunsuzluğudur. Öztürk vd.nin (2008) çalışmasında da bedensel engellilerin seyahatlerinde en önemli sorunlardan biri olarak transfer koşullarının yetersizliği vurgulanmıştır.

Engellilerin taleplerinin karşılanma düzeyinin yetersiz olduğu bildirilmiştir. Tatil organizasyonundan gerçekleştirme aşamasına kadar engellilerin yaşadıkları sorunlar arasında mimari engellerin en fazla sorun yarattığına ilişkin görüşler yer almıştır. Ray ve Ryder'in (2003) bedensel engellilerin tatil seçenekleri, tatil planlama ve seyahat aşamalarında beklentileri ve yaşadıkları sorunları araştıran çalışmasında engelli bireylerle yaptıkları odak grup görüşmesinde katılımcılar, "erişilebilir" olarak bildirilen tesislerin bile gerçek anlamda erişilebilir olmadığını, bu konuda acentelere güvenmediklerini belirtmiştir. Artar ve Karabacakoğlu'nun (2003) yaptı̆̆ araştırmada 4 ve 5 yıldızlı otellerin engellilere yönelik düzenlemeleri ortaya konulmuştur. Buna göre engellilere yönelik düzenlemesi olduğunu bildiren otellerin oranı $\% 61$ iken dü- 
zenleme olmadığını bildirenlerin oranı \%31 olarak bulunmuştur. Bu düzenlemeler arasında asansörde sesli uyarı sistemi olan otel oranı $\% 18$; 1şıklı ve yazılı uyarıcıları olanların oranı \%35; işitme engelliler için görsel levhaları olanların oranı \%21; havuza giriş için lift vb. özel sistemi olanların oranı $\% 9$ olarak bulunmuştur. Dolayısıyla bu sonuçlara bakıldığında özellikle hareketlilik konusunda düzenlemelerin yetersiz olduğu görüşünü destekler niteliktedir.

Engellilerin gereksinimlerinin karşılanması için turizm aracılarının görevleri konusundaki görüşler değişiklik göstermiştir. Grubun gereksinimlerine göre hizmetlerini, donanımını güçlendirmeleri, kendilerini eğitmeleri gerektiğine ilişkin görüşler dikkat çekmektedir. Engelli STK'larının ise temsil ettikleri grubun ihtiyaçları ve sorunları konusunda bilgilendirici rol üstlenmeleri gerektiği, öne çıkan bir görüş olmuştur. Devlete düşen görevler konusunda ise engelliye maddi destek vermesi gerektiğine yönelik görüşler ağırlıkta olmuştur. Devlet İstatistik Enstitüsü Başkanlığı ve Başbakanlık Özürlüler İdaresi Başkanlığı tarafından 2002'de yayınlanan Türkiye Özürlüler Araştırması verilerine göre engellilerin beklentileri arasında parasal katkı beklediğini ifade eden engelli birey oranı $\% 61,22$ iken iş bulmaya yardım beklentisinde olanların oranı \%9,55'tir. Eğitim olanaklarından yararlanma beklentisini ifade edenlerin oranı ise \%3,31 olarak bulunmuştur. Yine aynı çalışmaya göre engellilerin iş gücüne katılım oranı $\% 21,71$ olarak belirlenmiştir. Bu sonuçlar engellilerin maddi sıkıntı çektiğini ve devletten beklentisinin maddi destek olduğunu belirten katılımcıların görüşlerini destekler niteliktedir. İş gücüne katılamayan \%78,29'luk çoğunluğun tatil yapabilmesi için devlet desteği şart gibi görünmektedir. Bu bağlamda Miller ve Kirk (2002) tarafından yapılan çalışmada da benzer bulgular elde edilmiştir. Bu çalışmada elde edilen diğer bir bulgu da engellilerin turizmden yeterli ölçüde faydalanmalarında devletin büyük sorumluluk sahibi olması gerektiğidir.

Katılımciların, engellilerin turizm hizmetlerinden yararlandırılması için önerileri çeşitlilik göstermiştir. Ancak engellilerin maddi açıdan desteklenmesi ve mimari engellerin kaldırılmasına yönelik öneriler öne çıkmıştır. Bunun yanında hizmet götürecek kişilerin eğitilmesi konusuna da değinilmesi önemli görülmüştür. Toplumda engelli- ler konusunda farkındalık yaratılması, teşviklerin yapılması, turizm aktörleri arasında ortak aklın kullanılması yönünde önerilerde bulunulmuştur. Öztürk vd.nin (2008) çalışmasında da katılımcıların turizm endüstrisinde koşulların iyileştirilmesine yönelik önerileri arasında, toplumsal bilincin oluşturulması, hükümetin engellilerin seyahate katılımını artırıcı önemler alması, resmi ve özel kurumlarla işbirliği, otellerde fiziki değişikliklerin yapılması ve personelin eğitilmesi gibi önerilerde bulunulmuştur.

Engellilerin turizm faaliyetlerine katılmalarında, ulaşımdan kaynaklanan güçlükleri kurumların dikkate almaları (Cavinato ve Cuckovich 1992), havayollarının engelliler için yapmaları gereken düzenlemeleri hayata geçirmeleri (Abeyraine 1995), ihtiyaç duyulan bilgilere hızlı ve rahat bir biçimde ulaşabilmeleri (Brown vd. 1999) ve engellilerin seyahatlerinin tüm aşamalarında ihtiyaçlarını giderici tedbirleri almaları (Daniels vd. 2005) gerektiği ifade edilmektedir. Tütüncü ve Aydın'a (2013) göre, turizm sistemi içinde yer alan tüm turizm paydaşlarının, erişilebilirlik kapsamında ayrıntılı bir şekilde gerçekleşへtirmeleri gereken faaliyetler belirlenmelidir. Engelᄀli birey turistik bir hizmet aldığında, ulaşımından konaklamasına kadar her şey ulaşılabilir nitelikte olmalıdır. Bunların da ötesinde engellilerin de yaşam hakkı bulundu־ğundan, engellilere yönelik geliştirilecek her faali-yyet bir insanlık gereğidir.

Elde edilen bulgulara göre aşağıdaki önerileri sunmak mümkündür:

Engelli insanlar ile ilgili alınacak her kararda ve uygulanacak her tasarrufta engelli insanlar ve onları temsil eden sivil toplum örgütleri karar verme mekanizmasının merkezinde yer almalıdır. Ayrıca, engellilerin turizm aktivitelerinden engelsiz ve onurlu bir şekilde yararlanabilmesi için engelliler ile ilgili yasaların hızlı bir şekilde hayata geçirilmesi gerekmektedir. Bu şekilde, daha fazla engellinin turizm faaliyetine katılması sağlanacaktır.

Engelli insanların turizm faaliyetine katılmasında önemli bir engel olan ekonomik yetersizlikler konusunda devlet, sosyal bir devlet olmanın sorumluluğu doğrultusunda ekonomik katkı sağlamalıdır. Yılda en az bir kez olmak şartıyla ekonomik yetersizlikleri olan engelli insanların erişilebilir turizm hizmeti sunan turizm işletmeleri aracıll- 
ğıyla turizm faaliyetlerinden yararlanması sağlanmalıdır. Bu şekilde sadece engelli insanlar değil, aynı zamanda erişilebilir turizm hizmeti sunma konusunda turizm işletmeleri de teşvik edilmiş olacaktır.

Devlet, kamu sektörünün (bakanlıklar ve belediyeler), ulaştırma (havayolu, karayolu, denizcilik ve demiryolu) ve turizm (konaklama, seyahat ve yeme-içme vs.) işletmelerinin engelsiz turizm hizmetlerini evrensel tasarımla sunmaları için standartlar getirmelidir. Bu standartların uygulanması teşvik ve yaptırımlar yöntemiyle sağlanmalıdır. Belirtilen standartları sağlayan işletmelere "engelli dostu işletme" belgesi verilmelidir.

Erişilebilir turizm kapsamında turizm eğitimi veren okulların müfredatlarında engellilere yönelik hizmet unsurlarını içeren dersler olmalıdır. Bununla birlikte, engelli insanlara hizmet sunacak turizm elemanlarının yeterliliklerini belgeleyecek sertifika programları düzenlenmelidir. Sertifika programinda başarılı olan ve belge almaya hak kazanan turizm elemanlarının istihdam edilmesine öncelik verilmelidir.

Engellilik ve engelli insanlar hakkında toplumsal bilinç oluşturulmalıdır. Okullarda ve medyada bilinçlendirici, eğitici ve öğretici empati kurmaya yönelik çalışmalar yapılmalıdır. Bu çalışmalarda herkesin engelli adayı olduğu ve bir gün muhakkak geçici ya da kalıcı bir engellilik ile yaşamak zorunda kalacağı bilinci oluşturulmalıdır.

Ülkemizde çok fazla sayıda gizli engelli insan vardır. Devlet, sosyal sorumluluk gereği, engelli insanları ve ailelerini bilinçlendirerek evlerinde izole olmaları yerine topluma katılmalarını sağlamalıdır. Engelli insanların aile bireyleri refakatinde turizm faaliyetlerine onurlu bir şekilde katılmaları, bu insanların mutlu olmasına katkı sağlayacaktır.

Turizm işletmeleri engelliler için bir rehabilitasyon merkezi gibi algılanmamalıdır. Turizm işletmeleri engelli insanlar ile diğer insanların birlikte turizm faaliyetlerinden onurlu bir şekilde faydalanabileceği tesisler olarak hizmet sunmalıdır. Bu bağlamda mevcut kapasitede ek düzenlemeler yapilması daha uygun olacaktır.

Engellilerin turizm faaliyetlerine katılabilmeleri için doğru ve gerekli bilgilere erişilebilirlik büyük önem arz etmektedir. Engelli insanlara her konuda olduğu gibi turizm faaliyetleri konusunda da kamu yararına hizmet sunan kurumların bilgilendirme hizmeti sunan birimleri ve internette web siteleri olmalıdır. Ayrıca, kamu spotlarıyla tüm iletişim araçları kullanılarak bilgilendirme sürekli bir şekilde yapılmalıdır.

Engelli insanların turizm faaliyetlerine katılmalarıyla çok önemli ve özel bir turizm pazarı oluşmuştur. Sürdürülebilir turizm yaklaşımı kapsamında başta engelli insanların oluşturduğu pazara hizmet sunmayı öngören erişilebilir turizm yadsınamayacak bir öneme sahiptir. Sosyal devletin destekleri ve yaptırımlarıla engellilerin turizm faaliyetlerine katılması, hem engelli insanlar ve yakınları hem de turizm işletmeleri için yararlı olacaktır.

Sonuç olarak, yapılan bu çalışma, herhangi bir tür geçici veya kalıcı engellilik ile yaşamak zorunda kalan insanların eşit ve onurlu bir şekilde turizm faaliyetlerine katılmaları için katılımcıların görüşleri doğrultusunda öneriler sunmaktadır. Engelli insanların önünde başta ekonomik, fiziksel (genel alanlar, yapı iç ve dış mekânları) ve ulaştırma ile ilgili sorunlar bulunmaktadır. Bu çalışmada, belirtilen sorunları ortadan kaldırmaya yönelik yukarıda belirtilen önerileri uygulamak için devlet (kamu kurumları), sivil toplum örgütleri, yerel yönetimler, özel sektör, uzmanlar, engelli insanlar ve aileleri, toplum ve medyanın işbirliği ve eşgüdüm içerisinde olmaları gerektiği vurgulanmaktadır.

Engellilerin de turizm hizmetlerinden yararlanmasının hak olduğunun hatırlanarak, Türkiye'de engellilerin tatil olanaklarını, tatil seçimlerini, hareketlilikle ilgili ihtiyaçlarını, mevcut durumu sayısal verilerle ortaya koyacak ve konunun tüm aktörlerinin kapsamlı bir şekilde fikirlerini ortaya koyacak nicel araştırmalara gereksinim vardır. Yurtdışı kaynaklarda, bu konuyla ilgili çok sayıda çalışmaya rastlanmakla birlikte Türkiye'de yapılmış sınırlı sayıda çalışmaya rastlanması da bu konuda bilimsel yayınların yapılmasının gerekliliğini ortaya koymaktadır. Erişilebilir turizmin turizm endüstrisi içerisinde önemli bir paya sahip olabilmesi için yapılacak olan nitel ve nicel araştırmaların çok yönlü ve kapsamlı olarak ele alınması gerekmektedir. Yapılan bu çalışmanın, bu konuda yapilacak sonraki nitel çalışmalara bir kaynak olacağı, bu alanda yapılacak olan bilimsel nicel araştırmaların alt yapısını oluşturmasına katkı sağlayacağı ve engelli insanların turizm faaliyetlerine katılımı önündeki engellerin ortadan kaldırılmasına yönelik çalışmalara ışık tutacağı düşünülmektedir. 


\section{KAYNAKÇA}

Abeyraine, R.I.R. (1995). Proposals and Guidelines for the Carriage of Elderly and Disabled Persons by Air, Journal of Travel Research, 33 (3): 52-59.

AIHW (The Australian Institute of Health and Welfare - Avustralya Sağlık ve Sosyal Yardımlaşma Enstitüsü), Demand for Disability Support Services in Australia: Size, Cost and Growth 1997, http://www.aihw.gov.au/WorkArea/ DownloadAsset.aspx?id=6442455501, Erişim tarihi: 4 Temmuz 2013.

Akıncı, Z. (2013). Management of Accessible Tourism and Its Market in Turkey, International Journal of Business and Management Studies, 2 (2): 413-426.

Artar, Y. ve Karabacakoğlu, Ç. (2003). Türkiye'de Özürlüler Turizminin Geliştirilmesine Yönelik Olarak Konaklama Tesislerindeki Altyapı Olanaklarının Araştırılması, Özürlülerin Toplumsal Gelişimine Yönelik Proje. Milli Prodüktivite Merkezi, Ankara.

Ataseven, B. (2012). Nitel Bilimsel Araştırmalarda Veri Kalitesinin Önemi, Marmara Üniversitesi, İ.̇.B.F. Dergisi, 33 (2): 543-564.

Brown, T. J., Kaplan, R. ve Quaderer, G. (1999). Beyond Accessibility Preference for Natural Areas, Therapeutic Recreation Journal, 33 (3): 209-221.

Buhalis, D., Michopoulou, E., Eichhorn, V. ve Miller, G. ( 2005). Accessibility Market and Stakeholder Analysis - One-StopShop for Accessible Tourism in Europe (OSSATE). Surrey Üniversitesi, Birleşik Krallık.

Burnett, J. J. ve Baker, H. B. (2001). Assessing the Travel-related Behaviors of the Mobility-Disabled Consumer, Journal of Travel Research, 40 (1): 4-11.

Büyüköztürk, Ş., K1lıç Çakmak, E., Akgün, Ö. E., Karadeniz, Ş. ve Demirel, F. (2008). Bilimsel Araştırma Yöntemleri. Ankara: Pegem Yayınları.

Cavinato, J. L. ve Cuckovich, M. L. (1992). Transportation and Tourism for the Disabled: An Assessment, Transportation Journal, 31 (3): 46-53.

Chou, S. H. ve Chao, W. C. (2007). Seeing Voices: Travel Experience and Individual Risk of the Hearing Impaired, In Proceedings of the 2007 Advanced in Tourism Marketing Conference, Eylül 2007, Valencia, İspanya: 1-10.

Coles, T ve Shaw, G. (2003). Disability, Holiday Making and The Tourism Industry in The UK: A Preliminary Survey, Tourism Management, 25 (3): 397-403.

Daniels, M. J., Rodgers, E. B. D. ve Wiggins, B. P. (2005). “Travel Tales": An Interpretive Analysis of Constraints and Negotiations to Pleasure Travel as Experienced by Persons with Physical Disabilities, Tourism Management, 26 (6): 919-930.

Darcy, S. (1998). Anxiety to Access: Tourism Patterns and Experiences of Disabled New South Wales People with a Physical Disability Tourism. Sydney: South Wales.

Darcy, S. (2002). Marginalised Participation: Physical Disability, High Support Needs and Tourism, Journal of Hospitality and Tourism Management, 9 (1): 61-72.

Darcy, S. ve Dickson, T. (2009). A Whole-of-Life Approach to Tourism: The Case for Accessible Tourism Experiences, Journal of Hospitality and Tourism Management, 16 (1): 32-44.
Dwyer, L. ve Darcy, S. (2008). Economic Contribution of Disability to Tourism in Australia. Sustainable Tourism Cooperative Research Centre, Gold Coast: 15-21.

Eichhorn, V., Miller, G., Michopoulou, E. ve Buhalis, D. (2008). Enabling Access to Tourism through Information Schemes?, Annals of Tourism Research, 35 (1): 189-210.

Ekiz, D. (2003). Eğitimde Araştırma Yöntem ve Metotlarına Giriş. Ankara: Anı Yayıncilık.

ENAT (European Network for Accessible Tourism - Avrupa Erişilebilir Turizm A $\breve{g}_{1}$ ) What is Accessible Tourism?, www. accessibletourism.org/ ?i=enat.en.faq.744, Erişim tarihi: 2 Ağustos 2013.

Freeman, M., deMarrais, K., Preissle, J., Roulston, K. ve St. Pierre, E. A. (2007). Standards of Evidence in Qualitative Research: An Incitement to Discourse, Educational Researcher, 36: 25-32.

Germ, P. ve Schleien, S. (1997). Inclusive Community Leisure Services: Responsibilities of Key Players, Therapeutic Recreation Journal, 31: 22-37.

Glesne, C. ve Peshkin, A. (1992). Becoming Qualitative Researchers an Introduction. Londra: Longman Group Ltd.

Glesne, C. (2013). Nitel Araştırmaya Giriş. 2. Baskı (A. Ersoy ve P. Yalçınoğlu, Çev.), Ankara: Anı Yayıncılık.

Gröschl, S. (2007). An Exploration of HR Policies and Practices Affecting the Integration of Persons with Disabilities in the Hotel Industry in Major Canadian Tourism Destinations, Hospitality Management, 26: 666-86.

Hammerssley, M. (1998). Partisanship and Credibility: The Case of Anti-Racist Educational Research. İçinde: Connolly, P. ve Troyna, B. Eds. Researching "Race" içinde Educational Setting, Buckingham: Open University Press.

Huh, C. ve Singh, A. J. (2007). Families Traveling with a Disabled Member: Analyzing the Potential of an Emerging Niche Market, Tourism and Hospitality Research, 7 (3/4): 212-29.

Israeli, A. A. (2002). A Preliminary Investigation of the Importance of Site Accessibility Factors For Disabled Tourists, Journal of Travel Research, 41 (1): 101-104.

KTB. Kültür ve Turizm Bakanlığ1 Avrupalı Seçkin Destinasyonlar Projesi, http://disiliskiler.kulturturizm.gov.tr/TR,22229/ eden-european-destination-of-excellence--avrupali-secki-.html, Erişim tarihi: 20 Eylül 2013.

KTB (Kültür ve Turizm Bakanlığı). 2012 Yılı Konaklama İstatistikleri Raporu, Kültür ve Turizm Bakanlığı, http://sgb.kulturturizm.gov.tr/Eklenti/5913, isletme-ve-yatirim-belgeli-tesisistatistikleri.pdf?0, Erişim tarihi: 2 Eylül 2013.

Kümbetoğlu, B. (2005). Sosyolojide ve Antropolojide Niteliksel Yöntem ve Araștırma. İstanbul: Bağlam Yayıncılık.

Kvale, S. (1996). Interviews: An Introduction to Qualitative Research Interviewing. Kaliforniya: Sage Yayınları.

Lincoln, Y. S. ve Guba, E. (1985). Naturalistic Inquiry. Newbury Park, CA: Sage Yayınları.

Mayring, P. (2011). Nitel Sosyal Araştırmaya Giriş. (A. Gümüş, \& M. Durgun, Çev.), Ankara: BilgeSu Yayıncllı.

Miller, G. A. ve Kirk, E. (2002). The Disability Discrimination Act: Time for the Stick?, Journal of Sustanable Tourism, 10 (1): 82-88.

Neumann, P. ve Reuber, P. (2004). Economic Impulses of Accessible Tourism for All. Belge No 526, Ekonomi ve Çalışma Bakanlığı, Berlin. 
Nicolle, C. ve Peters, B. (1999). Elderly and Disabled Travelers: Intelligent Transport Systems Designed for the 3rd Millennium, Transportation Human Factors, 1 (2): 121-34.

Özdamar, K., Odabaşı, Y., Hoşcan, Y., Bir, A.A., Kırcaali, G., Özmen, A. ve Uzuner, Y. (1999). Sosyal Bilimlerde Araştırma Yöntemleri. Eskişehir: Anadolu Üniversitesi Yayınları, No:1081.

ÖZIDA (Özürlüler İdaresi Başkanlığı) (2010). Ulaşılabilirlik Stratejisi ve Ulusal Eylem Planı (2010-2011) Raporu, Özürlü ve Yaşlı Hizmetleri Genel Müdürlüğü, Ankara.

ÖZIDA (Özürlüler İdaresi Başkanlığı) Birleşmiş Milletler Engelli Hakları Sözleşmesi, http://www.ozida.gov.tr/ulasilabilirlik/Belgeler/2_MEVZUATSTANDART/ULUSLARARASI SOZLESME/BM_ENGELLIHAKLARISOZLESMESI.pdf, Erişim tarihi: 1 Eylül 2013.

Öztürk, Y., Yaylı, Y. ve Yeşiltaş, M. (2008). Is the Turkish Tourism Industry Ready for Disabled Customer's Market? The Views of Hotel and Travel Agency Managers, Tourism Management, 29: 382-389.

Poria, Y., Reichel, A. ve Brandt, Y. (2011). Dimensions of Hotel Experience of People with Disabilities: An Exploratory Study, International Journal of Contemporary Hospitality Management, 23 (5): 571-591.

Ray, N. M. ve Ryder, M. E. (2003). Ebilities" Tourism: An Exploratory Discussion of the Travel Needs and Motivations of the Mobility-disabled, Tourism Management, (24): 57-72.

Şimşek, H. ve Yıldırım, A. (2006). Nitel Araştırma Yöntemleri. Ankara: Seçkin Yayıncılık.

Small, J., Darcy, S. ve Packer, T. (2012). The Embodied Tourist Experiences of People with Vision Impairment: Management Implications beyond the Visual Gaze, Tourism Management, 33: 941-950.

Smith, R.W. (1987). Leisure of Disable Tourists: Barriers to Participation, Annals of Tourism Research, 14 (3): 376-389.
Tellan, D. ve Yılmaz, A. (2007). Turizm Sektöründe Sayısal Ortamların Kullanımını Değerlendirmek: Türkiye Örneği, Çeşme Ulusal Turizm Sempozyumu, 21-23 Kasım, İzmir.

TUIKK (Türkiye İstatistik Kurumu). Türkiye Özürlüler Araştırmas1 2002, http://kutuphane.tuik.gov.tr/pdf/0014899.pdf, Erişim tarihi: 8 Mayıs 2013.

Turco, D. M., Stumbo, N. ve Garncarz, J. (1998). Tourism Constraints - People with Disabilities, Parks and Recreation Journal, 33 (9): 78-84.

TÜRSAB (Türkiye Seyahat Acentaları Birliği). Dünyada ve Türkiye'de Engelsiz Turizm Pazar1 2008 Raporu, http:// www.tursab.org.tr/tr/engelsiz-turizm/dunyada-ve-turkiyedeengelsiz-turizm-pazari_487.html, Erişim tarihi: 18 Ocak 2013.

Tütüncü, Ö. ve Aydın, İ. (2013). Ulaşılabilir Turizm, Anatolia: Turizm Araştırmaları Dergisi, 24 (2): 261-263.

Van Horn, L. (2007). Disability Travel in the United States: Recent Research and Findings, 11th International Conference on Mobility and Transport for Elderly and Disabled Persons, the Palais des congrès de Montréal.

WHO (World Health Organization- Dünya Sağl1k Örgütü). Summary World Report On Disability 2011, http://www. who.int/disabilities/world_report/2011/ accessible_en.pdf, Erişim tarihi: 5 Temmuz 2013.

WHO (World Health Organization- Dünya Sağlık Örgütü) Turizmde Global Etik İlkeler 1999, http://ethics.unwto.org/sites/all/files/docpdf/turkey.pdf, Erişim tarihi: 6 Temmuz 2013.

Yates, K. (2007). Understanding the Experience of Mobility-Disabled Tourists, International Journal of Tourism Policy, 1 (2): 153-66.

Yau, M. K., McKercher, B. ve Packer, T. L. (2004). Traveling with a Disability: More Than An Access Issue, Annals of Tourism Research, 31 (4): 946-960.

Yaylı, A. ve Özürk, Y. (2006). Konaklama İşletmeleri Yöneticilerinin Bedensel Engelliler Pazarına Bakış Açıları Üzerine Bir Araştırma, Anatolia: Turizm Araştırmaları Dergisi, 17 (1): 87-97. 